\title{
Spatial and temporal variation of three biomarkers in Mytilus edulis
}

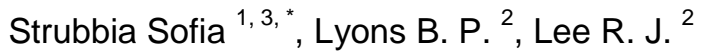

${ }^{1}$ IZSUM, Perugia, PG, Italy.

${ }^{2}$ Ctr Environm Fisheries \& Aquaculture Sci, Barrack Rd, Weymouth DT4 8UB, Dorset, England.

${ }^{3}$ IFREMER, Rue lle Yeu,BP 21105, F-44311 Nantes 03, France.

* Corresponding author : Sofia Strubbia, email address : sofia.strubbia@ifremer.fr

\begin{abstract}
:
Environmental conditions and xenobiotic exposure can be sources of stress to living organisms. Biological markers are measurable indicator of changes which may happen at any biological level and which can be considered an early warning signal of some biological or environmental state or condition. A structured field study was undertaken to investigate the relationship between three biomarker assays and the spatial and temporal variation of each biomarker in samples of Mytilus edulis. The three biomarkers were the neutral red retention assay, micronucleus assay and comet assay, which indicate damage at different cellular/molecular levels. Three sites in Poole Harbour, an area on the South coast of the UK were sampled on six separate occasions at least three weeks apart. The results for the comet assay showed a significant difference between sites and between sampling dates whereas the results for the other two assays did not show a significant difference for either factor. There was no significant correlation between the results of any pair of the three biomarkers. The results of the micronucleus assay showed a significant correlation with water temperature. This temperature effect, as well as induced repair, may contribute to explain the lack of a strict correspondence between pollution gradients and biomarkers responses.
\end{abstract}

\section{Highlights}

- The CA results, but not those of NRR or MN, showed a significant variation with respect to sampling site and date. No significant correlation between NRR or CA and any of the measured environmental variables (temperature, salinity, $\mathrm{pH}$ ). - The MN Index showed a significant correlation with water temperature but no significant correlation with salinity or $\mathrm{pH}$. There was no correlation reported between the results of the three biomarkers (NRR, MN and CA).

Keywords: Mytilus edulis, Biomarkers, Stress, Neutral red retention, Comet assay, Micronucleus assay, Poole Harbour 
35 This work was funded by DG Santé of the European Commission and was undertaken as

36 collaboration between the European Union Reference Laboratory for Monitoring

37 Bacteriological and Viral Contamination of Bivalve Molluscs and the Istituto Zooprofilattico

38 Sperimentale dell'Umbria e delle Marche. Authors would like to acknowledge John Bignell

39 and Tim Bean for the technical support they provided during the present work.

\section{Introduction}

41 Poole Harbour, located in the South of England, is a large natural harbour which contains

42 numerous active commercial bivalve harvesting areas (Food Standards Agency, 2017). The

43 northern and western region of the harbour contains industrial and urban centres and more 
sources of anthropogenic pollution compared to the southern sections. Discharges of industrial waste have resulted in high concentrations of metals including cadmium $(\mathrm{Cd})$, mercury $(\mathrm{Hg})$, copper $(\mathrm{Cu})$, silver $(\mathrm{Ag})$, nickel $(\mathrm{Ni})$ and zinc $(\mathrm{Zn})$ in the northern part of the harbour (Bryan \& Langstone, 1992; Turner A. 2000; Poole Harbour Steering group, 2011). Additional contamination arises from leisure marine activities and the commercial port operation, again concentrated on the northern side of the harbour. In the past, these activities have contributed to the historic contamination of the harbour by tributyltin (TBT) (Langston et al., 2015). The presence of many of these compounds in Poole Harbour has been described by Cefas in the SEA8 final report (2007), which focused on the assessment of major contamination inputs and on their resulting contamination of the environment. The south side of the harbour is potentially impacted by two oil production facilities: one located on land and the other on an island within the harbour. However, PAH and metal values in sediments from Poole harbour, while exceeding certain sediment quality guidelines, are relatively low when compared with other heavily industrialised ports and harbours around the coast of England and Wales (Cefas, 2007; Nicolaus 2015). The western side of the harbour is mainly impacted by agricultural activity resulting in elevated concentrations of inorganic nitrogen levels, which are about six times higher in this section of the harbour (Environment Agency, 2013). Biological effect markers are represented by any physiological and structural alteration that may occur at any level of the organism as response to environmental changes, both natural and anthropogenic. Biomarkers are defined as quantitative measures of any biochemical, physiological or behavioural changes occurring in an organism in response to external factors that can be a source of stress as xenobiotic exposure. The changes may be measured in cells, body fluids, tissues or organs and are typically intended to provide an early warning signal of biological effect due the fact that the sub-cellular or biochemical responses measured tend to precede those that occur at an organism or population level (Lam \& Gray, 2003; Martin-Diaz et al., 2004; Schettino et al., 2012). Due to the dynamic equilibrium of the marine environment, the use of a battery of biomarkers allows an integrated assessment of effects at chemical, cellular, sub-cellular, tissue and whole organism levels. Bivalve mussels have a long history of use to indicate the extent of environmental contamination by a wide range of chemical compounds (International Mussel Watch Committee; Intergovernmental Oceanographic Commission, 1992). More recently they have also been used in the field to determine the effects of such contamination using biomarkers (Brooks et al., 2009; Shaw, et al., 2011). A combination of three different biomarkers in Mytilus edulis (common or blue mussels) was selected for the present study, neutral red retention (NNR) assay provides an indicator of general cellular stress, while the comet assay and micronucleus assay are both markers of genotoxicity and represent a more specific indicator of DNA damage. The NRR assay had been developed to determine the lysosomal membrane stability of mussel haemocytes (Zhao et al., 2011). It is basically a stress assay, which consist in verifying the stability of the lysosomal membrane by putting it in contact with the neutral red dye. When the lysosomal membrane, or possibly the $\mathrm{H}+$ ion pump, is destabilized, neutral red leaks into the cytosol of the cell much more quickly than in an unstressed cell (Zhao et al., 2011). The damage detected by this assay may be due to several factors such as exposure to heavy metals $(\mathrm{Cu}, \mathrm{Cd}, \mathrm{Hg})$ or organic pollutants as well as natural factors such as extremes variations of temperature or salinity (Dailianis et al., 2003; Loayza-Muro \& Elias-Letts, 2007; Aguirre- 
Martìnez, 2013) and the final stage of gametogenesis and spawning, which is a natural stressful process.

The micronucleus assay $(\mathrm{MN})$ detects fragments of chromosomes that result from anomalies during the cell division phase (Barsiene et al., 2006). Their presence is an indicator of genotoxic effect and may indicate the presence of organic and inorganic substances such as polycyclic aromatic hydrocarbons, heavy metals and organochlorinated compounds (Brunetti et al., 1992; Magni et al., 2006; Dailianis et al., 2003; Bolognesi \& Fenech, 2012). The frequency of $\mathrm{MN}$ formation is considered to be a suitable index of a time-integrated response to cumulative stress following exposure to environmental contaminants.

Similar to MN assay, the comet assay (CA) is a measurement of genotoxicity that may result from exposure to numerous chemical contaminants (Frenzilli et al., 2009). The assay is rapid, simple and produces a linear dose response to exposure e.g. ultraviolet (UV)-induced pyrimidine dimers, oxidized bases, and alkylation damage (Collins et all. 1996; Azqueta et al., 2011), or to a fuel oil spill (Lewis et al., 2010). The direct measurement of DNA damage is due to the evaluation of tails formed during the electrophoretic migration of the nuclear material. The degree of damage can be evaluated as either the tail moment (a function of tail length and fraction of DNA in tail) or the percentage of DNA in tail (also known as tail intensity) (Kwok et al., 2013; Mamaca et al., 2005; Lyons et al., 2012; Rank et al., 2005).

The NRR assay therefore gives an indication of general cellular stress and it has been used widely as a biomarker of the impact of chemical contaminants or other adverse environmental conditions (Dondero et al., 2006; Shaw et al., 2011). The MN and CA are both markers of genotoxicity and therefore give a more specific indicator of DNA damage, if compared to NRR. Increases in the frequency of micronuclei and/or increased tail length in the CA are expected in response to specific chemicals with genotoxic properties. Although the biomarkers chosen for the present study have been previously demonstrated in laboratory studies to respond in a concentration-dependent manner to several compounds (Galloway et al., 2002), they are not specific for the effects of one single pollutant. Moreover, they reflect the impact of a suite of environmentally relevant contaminants, able to affect the exposed animals (Lewis et al., 2010).

The purpose of the present work was to compare the biological effect on the shellfish at site assessed as being exposed to differing levels of sewage and chemical pollutants under a range of environmental conditions. NRR, MN assay and CA were used to evaluate the health condition of the mussels and the occurrence of a stress syndrome. It was planned to locate mussels in bags at three different locations within one area with sampling undertaken approximately every 15 days over a four-month period. After each sampling occasion mussels were replaced with other bagged depurated mussels.

\section{Materials and methods}

\subsection{Sampling sites}


Three sampling sites were selected within the harbour intended to represent different contamination sources and environmental influences (see Figure 1):

3 Site 1: it was located within a bay in the northern part of the harbour. This bay is subject to

4 the greatest amount of historical and current contamination from historical and current

5 industrial, maritime and sewage sources.

6 Site 2: it was located on the eastern side of Arne Peninsula which contains a nature reserve with an associated farm. This was expected to be subject to moderate amounts of anthropogenic contamination arising from the northern side of the harbour as well as some sewage and agricultural contamination arising from the western side of the harbour.

Site 3: it was located near to the entrance of the harbour and was selected as likely to be the least contaminated site. The only identified local sources were a small sewage discharge located approximately $2 \mathrm{~km}$ to the south-west and the Furzy Island oil operation located approximately $2 \mathrm{~km}$ to the north-west. The large tidal flows through the nearby mouth of the harbour were considered likely to reduce the effect of any impacts from those sources.

All sites were therefore potentially subject to impact to different extents from known sources of contamination and there was the possibility of other unknown sources. Therefore, it was considered that it was not appropriate to consider any of the sites as a control for comparative purposes.

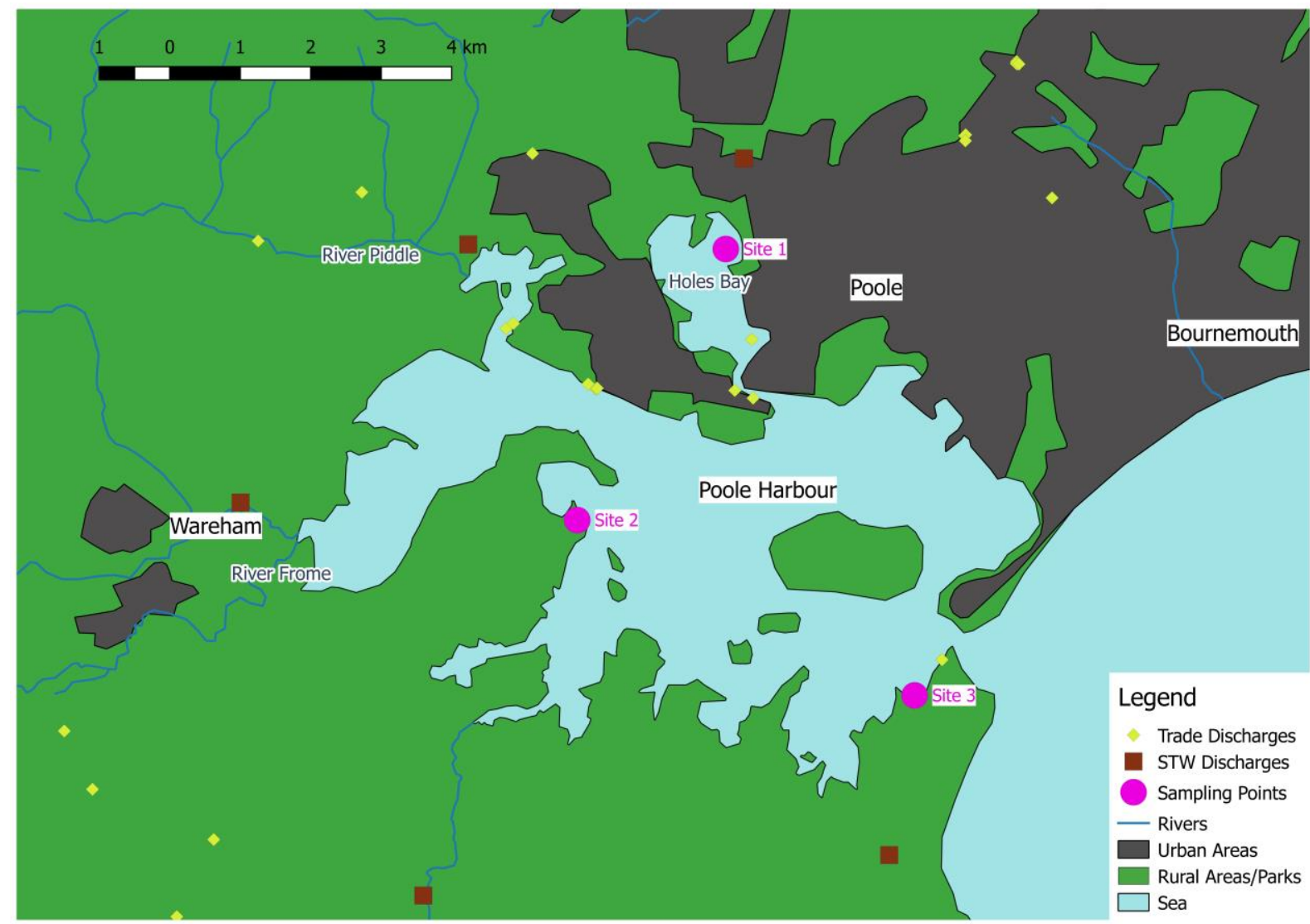

This map contains Environment Agency information $\odot$ Environment Agency and/or database right 
1 Figure 1. Study area showing sampling sites and potential sources of contamination

\subsection{Sampling and on-site measurements}

As previously described (Strubbia et al., 2016), bagged depurated Poole Harbour mussels (approximately $1.5 \mathrm{~kg}$ ) obtained from a local depuration center, were placed intertidally at each site 15 days prior to each planned sampling occasion. Immediately after sampling, any mud or other sediment adhering to the shells was removed by scrubbing/rinsing with seawater from the immediate vicinity of the sampling site while avoiding re-immersion. Sampling of mussels, together with collection of physicochemical measurements, was undertaken on six occasions between November 2013 and January 2014, generally around low water springs in order to facilitate access to the intertidal sampling locations. The mussels in each bag were split into three equal quantities and placed into appropriately labelled plastic bags. Transport of samples was undertaken in insulated boxes with cool packs in order to maintain a temperature ranging between $1^{\circ} \mathrm{C}$ and $8^{\circ} \mathrm{C}$. The duration from the time of sampling to the arrival at the laboratory was always less than 6 hours and analyses started within 24 hours of sampling. Between arrival at the laboratory and the start of analysis, all samples were stored at $4{ }^{\circ} \mathrm{C}$.Seawater salinity was measured at the time of sampling using either a YSI Professional Plus meter with conductivity and temperature probe or a YSI castaway Conductivity/Temperature/Depth (CTD) recorder calibrated using a 35 practical salinity unit standard.

\subsection{Haemolymph extraction for biomarker assays}

Haemolymph was extracted from a total of 12 mussels for each sample following the method reported by Moore et al. (Moore, et al., 2004). Briefly, the mussel valves were prised apart along the ventral surface, using a solid scalpel and $0.1 \mathrm{ml}$ of haemolymph from the posterior adductor muscle was extracted into a hypodermic syringe containing $0.1 \mathrm{ml}$ of physiological saline, withdraw. The contents were transferred to a $1.5-2.0 \mathrm{ml}$ siliconized microcentrifuge tube and stored in a refrigerator for up to 20 minutes prior to use. The haemolymph from each sample of mussels was stored in four separate vials, each containing the haemolymph from three different animals. The use of pooled samples of haemolymph allowed the examination of a large number of animals while keeping the number of individual biological marker test replicates to a practical level. A sample size of at least 10 mussels per site has been determined as being sufficient for the assessment of the environmental genotoxicity levels and evaluation of the existence of genetic risk zones (Baršienè, et al., 2012).

\section{2,4 NRR assay}

The method used in the present work was previously described by Moore et al. (ICES 2004). Fifty microlitres of the collected haemolymph were placed on a microscope slide and placed in a dark room for 15 min to allow adherence to occur. Fifty microliters of a $200 \mu \mathrm{M}$ neutral red solution were then added and incubated for 50 minutes, again in the dark. Those cells showing release of dye into the cytosol were deemed to be showing lysosome membrane damage. Fifty cells were counted per slide and results were expressed as the number of 
1 damaged cells out of fifty. A proportion of 50\% or more of the cells exhibiting lysosomal leakage is considered to show evidence of a stress condition (Ringwood et $a l, 2005$ ).

\subsection{MN assay}

The MN assay was undertaken by the method of Bolognesi and Fenech (2012). One hundred microliters of pooled haemolymph were placed onto a microscope slide and immediately placed in a humid chamber for $15 \mathrm{~min}$; the microscope slides were left to dry on the bench for at least 5-10 min. The cells were fixed with $100 \%$ methanol for $10 \mathrm{~min}$ followed by further air-drying for $10 \mathrm{~min}$ at room temperature. Dried slides were stained with 3\% (vol/vol) Giemsa solution for $5 \mathrm{~min}$ at room temperature, then rinsed in washing solution, prepared by adding $3 \mathrm{ml}$ of Sorensen buffer to $196 \mathrm{ml}$ of distilled or deionized water, and air-dried. Coverslips were applied and slides were examined using transmitted light microscopy at $\times 1,000$ magnification.

The ICES Cooperative Research Report (Baršienè, 2012) diagnostic criteria for micronucleus identification were used. These are:

- the micronucleus is less than $1 / 3$ of the size of the main nucleus.

- micronuclei are round- or ovoid-shaped, non-refractive chromatin bodies located in the cytoplasm of the cell and can, therefore, be distinguished from artefacts

- micronuclei are not connected to the main nuclei, and the micronuclear boundary should be distinguishable from the nuclear boundary.

One thousand cells were examined per slide, with four replicate slides per sample, each representing a separate haemolymph pool. The $\mathrm{MN}$ index for the sample was determined as the mean number of micronuclei per thousand cells over the four slides.

\subsection{Comet Assay}

The method used in the present work was performed according to guidelines published by ICES (Lyons, et al., 2012). Samples were cryopreserved using the method described by Kwok et al. (2013) in order that the assay could be undertaken when convenient. Prior to the assay, samples were left defrost at ambient temperature. Ten microlitres of haemolymph were placed in $160 \mu \mathrm{l}$ of low melting point (LMP) agarose $(0,7 \% \mathrm{w} / \mathrm{v}$ in Phosphate-buffered saline (PBS) $\left(\mathrm{Ca}^{++}, \mathrm{Mg}^{++}\right.$free): Dulbecco's PBS pH 7.4) previously heated and kept warm in the incubator at $37^{\circ} \mathrm{C} ; 50 \mu 1$ were placed onto a separate circle on a Trevigen Comet Slide ${ }^{\circledR}$. During the placement of the agarose the slide was kept in the dark and on ice, and then left in fridge for 10 minutes to set. A lysis working solution was prepared thirty minutes prior to use adding $1 \%$ Triton $\mathrm{X}-100$ and $10 \%$ DMSO to the stock solution $(2.5 \mathrm{M} \mathrm{NaCl}, 100 \mathrm{nM}$ EDTA, 10nM Trizma base in distilled water).Slides with the embedded cells were immersed in the lysis working solution for 30 minutes in the fridge in order to ensure the digestion of cellular and nuclear constituents. Slides were then placed in an electrophoresis tank with Alkaline Electrophoresis Solution $\mathrm{pH}>13(300 \mathrm{mM} \mathrm{NaOH}, 1 \mathrm{mM}$ EDTA) and incubate for 30 minutes. Electrophoresis was performed at 0.7 volts per $\mathrm{cm}$ and $300 \mathrm{~mA}$ for 30 minutes. At the end of 
1 buffer (0.4M Tris base; prepared with $48.44 \mathrm{~g}$ of Tris made up to $1000 \mathrm{~mL}$ with distilled water

2 and adjusted to $\mathrm{pH} 7.5$ using concentrated hydrochloric acid). They were then fixed with

$3100 \%$ methanol for 5 minutes. Immediately before reading the slides were rehydrated and

4 stained with the DNA specific fluorescent dye, SYBR Gold, and read using 40x magnifications. 50 cells per slide were counted. Four slides per experimental point were scored at each sampling occasion. The tails were evaluated through Comet Assay IV analysis software (Perceptive Instruments Ltd) and Camera AVT smart view for, Fire Package version 1.6.2) to measure the total image fluorescence intensity, head intensity, tail intensity, head length and tail length. The results were recorded as the \% tail intensity over 50 cells.

2.7 Data analysis

Graphs were prepared in Microsoft Excel 2016 (Microsoft Corporation) and statistical analyses were undertaken using Minitab v16 (Minitab Ltd). Probability plots were prepared for the data for each of the biomarkers and a fit to a normal distribution assessed using the Anderson-Darling test. The graphs (not shown) for all three biomarkers showed a reasonable fit to a normal distribution and the probability values for the Anderson-Darling test markedly exceeded 0.05 in each case. Therefore, non-transformed biomarker data were subsequently used for statistical analyses and graphical display. Analysis of the biomarker data by site and sample collection date was undertaken using General Linear Modelling. No assumptions were made about the distribution of the environmental variables and therefore Spearman's Rank Correlation was used to investigate any association between the results of the biomarker assays and the environmental variables.

\subsection{Mapping}

The map shown in Figure 1 was prepared using QGIS v2.18.13 (https://www.qgis.org/). A database of consented discharges to controlled waters was downloaded from the UK government data repository (https://data.gov.uk/dataset/consented-discharges-to-controlledwaters-with-conditions; downloaded 19/10/2017; metadata given on source page). Data tables were exported to Microsoft Excel 2016, duplicate entries removed and separate tables for discharges relating to sewage treatment works (STWs; which may contain allowed discharges of industrial effluents) and trade discharges (discharges from commercial premises, including those containing industrial effluents) were exported as comma separated variable (.csv) files to allow import into QGIS).

\subsection{Association between biomarkers}

Statistical analyses showed the lack of a significant correlation $(\mathrm{p} \geq 0.05)$ between the three biomarkers. Other authors already reported similar results showing that living organisms may 
2000 ; Forbes et al. 2009). These observations support the importance to select a battery of biomarkers in order to detect pollution effects on the environment since different stressors may induce a different effect on the studied organisms. Sometimes the use of biological markers for environmental monitoring may be controversial. Buchelli and Fent (2009) showed correlation between the induction of cytochrome P4501A and various contaminant (e.g. PAHs, coplanar PCBs, polychlorinated dibenzofurans, and dibenzodioxins). But they also highlighted that multiple factors can inhibit, or modify, biomarker responses, such as species, age and reproductive stage of the living organism, or physical environmental parameters as temperature or the presence of possible inhibitors. Furthermore, the lack of any significant correlation between the results of any two of the three biomarkers complicates the assessment of the state of contamination of the different sites within Poole Harbour. As well as the effect of temperature on MN Index, considered above, another aspect that may have affected the results is that DNA repair mechanisms are often triggered as compensatory response to damage. Several authors, as Nicholson \& Lam (2005) and Siu et al. (2004), discussed the presence of a threshold-dependent DNA repair system. Siu et al. studied the possible application of $\mathrm{CA}$ and $\mathrm{MN}$ assays to the detection of benzo[a]pyrene (B[a]P) in mussels. The authors suggested that a DNA repair system may be activated after the mussel tissue has accumulated sufficient toxicant above a threshold level, as previously observed also by other authors as Ching et al. (2001), Nicholson (2001) and Siu et al. (2003).

\subsection{Biomarker temporal and spatial variability}

Scatterplots of the results of the three biomarker assays are shown in Figure 1 and a summary of the output of the General Linear Modelling is presented in Table 1. No significant difference was seen between either site or sampling date for either NRR or MN Index. On the contrary, with the comet assay, a statistically significant difference was seen between sites (0.031) and between sampling dates $(<0.001)$. The highest mean value in the comet assay was seen at Site 3 (39.8\% tail intensity) although the maximum individual value was seen at Site 1 in November 2013 (53.8\%). The lowest mean value was seen at Site 2 (38.5\%). There was a tendency for the magnitude of the comet assay results at all sites to decline over the period of the study. Additional analysis using Tukey's method showed that, at the $95 \%$ confidence level, Site 1 had a significantly higher mean value than Site 2 and the two sampling occasions in November had significantly higher mean values than those in mid-December and January. On the three occasions that results were available for all three sites, site 2 yielded lower values than the other two sites (see Figure 2c).

The biomarker results for Site 1 were expected to be higher than the other two sites due to the concentration of historic and present-day sources of contamination in the vicinity. It has been assumed that site 3 would yield the lowest results with all assays due to its distance from most sources of contamination. However, it is possible that locations around the narrow harbour mouth are impacted from multiple sources within the harbour over the ebb tide, thus yielding the observed results with the comet assay.

The temporal pattern in the results of the CA did not result from the effects of any of the measured environmental variable (see below) and may reflect either other environmental 
1 variables or changes in other stressors such as the concentration of contaminants in the water 2 column. The latter could be due to variation in either the level of actual inputs or in the 3 amount of sediment-associated contamination associated with resuspension events.

4 
a.

2

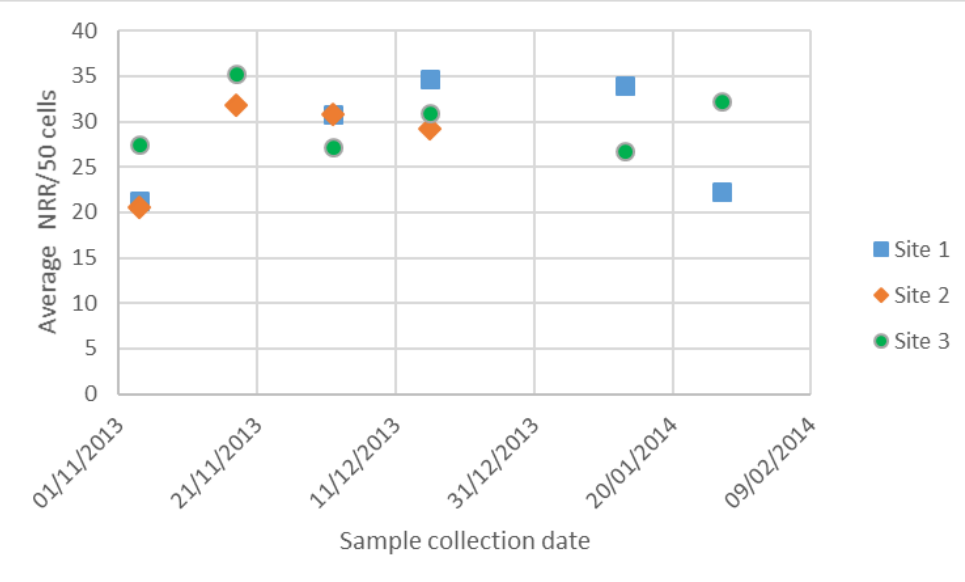

3

b.

4

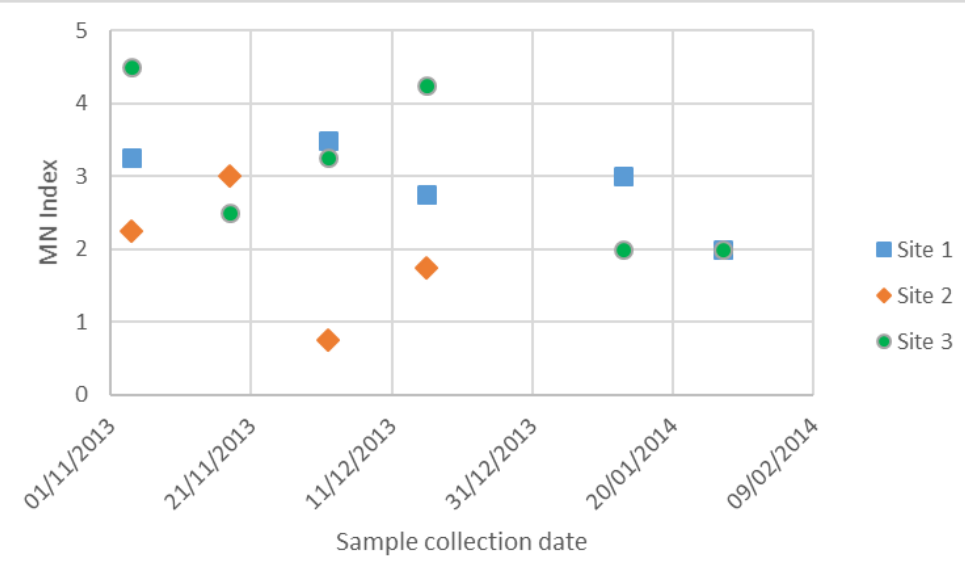

5

c.

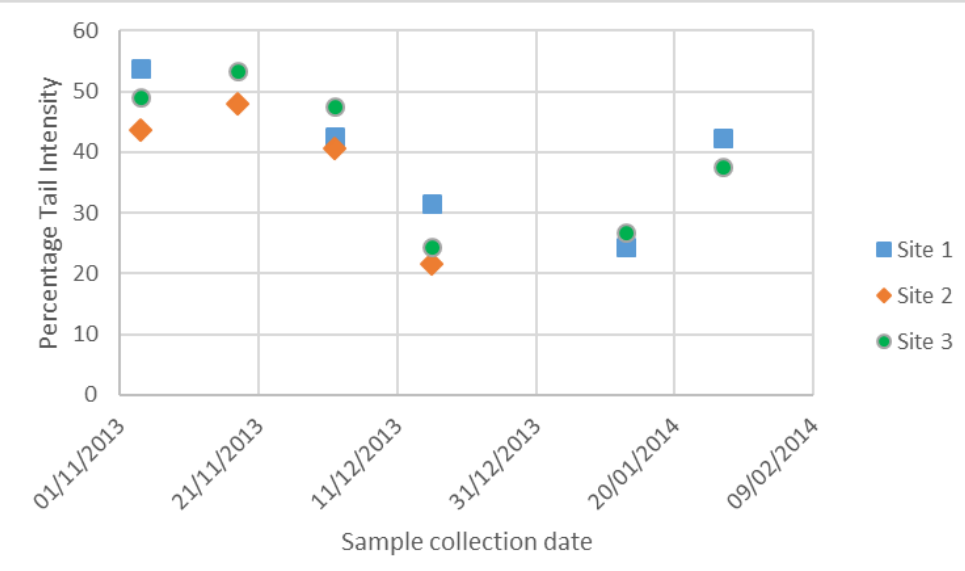

7 Figure 2. Results of biomarker assays by sampling site and date

a. NRR b. MN index c. CA 
1 Table 1. Summary of GLM output from the analysis of biomarker results by site and date

\begin{tabular}{|l|l|l|l|}
\hline Biomarker & Source of variation & F & P \\
\hline NRR & Site & 0.37 & 0.703 \\
& Date & 2.06 & 0.187 \\
\hline MN Index & Site & 3.72 & 0.079 \\
& Date & 1.26 & 0.377 \\
\hline CA & Site & 5.96 & 0.031 \\
& Date & 38.04 & $<0.001$ \\
\hline
\end{tabular}

2

3

4

5 6

\begin{tabular}{|l|c|c|c|}
\hline & \multicolumn{3}{|c|}{ Mean } \\
& \multicolumn{3}{|c|}{ (minimum, maximum) } \\
\hline Site & Temperature $\left({ }^{\circ} \mathrm{C}\right)$ & Salinity (PSU) & $\mathrm{pH}$ \\
\hline Site 1 & 10.2 & 21.3 & 7.4 \\
& $(7.4,11.9)$ & $(14.6,24.9)$ & $(6.4,8.5)$ \\
\hline Site 2 & 8.9 & 23.6 & 7.7 \\
& $(6.8,10.3)$ & $(18.5,26.7)$ & $(7.3,8.5)$ \\
\hline Site 3 & 9.1 & 29.6 & 8.0 \\
& $(7.0,11.3)$ & $(24.0,32.8)$ & $(7.6,8.7)$ \\
\hline
\end{tabular}

\subsection{Relationship between environmental variables and biomarkers}

10

11 No significant correlation was seen between the results of either NRR or CA and any of the 12 environmental variables ( $\mathrm{p} \geq 0.05$ ). The MN Index showed a significant correlation with water 13 temperature $(\mathrm{Rs}=0.58, \mathrm{p}=0.022)$ but no significant correlation with salinity or $\mathrm{pH}$.

14 The only significant association between the biomarker results and the three environmental 15 variables that were measured was that between MN Index and temperature. The observed 
correlation with water temperature is an effect previously reported by Bolognesi and Fenech (2012), who stated that temperature may be considered a confounding factor because it seems have a direct effect on the mitotic rate and consequently on the extent of $\mathrm{MN}$ expression. The temperature range recorded during the study period was relatively restricted (6.8 to 11.9) and the results do not preclude an effect of temperature on NRR or comet assay if the study was extended over a greater part of the year, and therefore a wider temperature range. The effect of temperature on MN Index in this study may have affected the ability to detect spatial differences with this biomarker and affected the relationship between it and the results of the comet assay: Siu et al (2004) had previously shown good correlation between MN Index and the CA results in haemolymph from Perna viridis exposed to benzo[a]pyrene under controlled laboratory conditions.

\section{Conclusions}

Holes Bay, an area subject to both historical and ongoing contamination, showed the highest mean CA level, which conformed to the expectation at the start of the work. However, the observation that the mean CA level at the site near the harbour entrance was not significantly lower than this was not expected: this could be due to unidentified local sources of one or more contaminants.

The lack of correlation between the results of the three biomarkers supports the importance of selecting a battery of biomarkers to detect the effects of pollutants in the environment. Multiple factors can inhibit, or modify, biomarker responses, such as species, age and reproductive stage of the living organism, or physicochemical parameters of the environment or the presence of possible inhibitors. Furthermore, the absence of correlation between sites may be due to levels of contamination too low to cause an effect in the assessed biological systems. Weak differences in concentrations between sites, may also explain the luck of significant effect over and above the underlying variability in the assay results.

\section{HIGHLIGHTS}

- The CA results, but not those of NRR or MN, showed a significant variation with respect to sampling site and date.

- No significant correlation was seen between the results of either NRR or CA and any of the three measured environmental variables (temperature, salinity, $\mathrm{pH}$ ).

- The MN Index showed a significant correlation with water temperature but no significant correlation with salinity or $\mathrm{pH}$

- There was no correlation between the results of the three biomarkers, neutral red retention (NRR), micronuclei index (MN) and comet assay (CA).

\section{REFERENCES}


Aguirre-Martìnez GV., Buratti S., Fabbr E., Del Valls A.T., Martìn-Dìaz M.L., 2013. Using lysosomal membrane stability of haemocytes in Ruditapes philipinarum as a biomarker of cellular stress to assess contamination by caffeine, ibuprofen, carbamazepine and novobiocin. Journal of Environmental Science 25, 1408-1418.

Azqueta A., Shaposhnikov S. and Collins A.R., 2011. DNA Repair Measured by the Comet Assay. In "DNA Repair" edited by Kruman, pp615-636. InTech Open Access available at: http://www.intechopen.com/books/dna-repair/dna-repair-measured-by-the-comet-assay

Baršienė J., Syvokiene, J. and Bjornstad, A., 2006. Induction of micronuclei and other nuclear abnormalities in mussels exposed to bisphenol A, diallyl phthalate and tetrabromodiphenyl ether-47. Aquat. Toxicol. 78 (Suppl. 1), S105-S108.

Baršienè L., Lyons B., Rybakovas A., Martìnenz-Gòmez, Andreikenaite L., Brooks S., Maes T. 2012. Background document: micronucleus assay as a tool for assessing cytogenetic/DNA damage in marine organisms. ICES Techniques in Marine Environmental Sciences, No. 315, 71-83.

Bolognesi C., Fenech M., 2012. Mussel micronucleus cytome assay. Nature Protocols 7, 1125-1137.

Borough of Poole and Poole Harbour Commissioners (2004). Poole Harbour Approach Channel Deepening and Beneficial Use of Dredged Material EIA: Environmental Scoping Study. Final Report, February 2004.

http://www.phc.co.uk/downloads/channeldeepening/rmas_scoping.pdf

Bowgen K. M., Stillman R. A., Herbert R. J.H., 2015. Predicting the effect of invertebrate regime shifts on wading birds: Insights from Poole Harbour, UK. Biological Conservation $186,60-68$.

Brooks S., Lyons B., Goodsir F., Bignell J. and Thain J., 2009. Biomarker responses in mussels, an integrated approach to biological effects measurements. Journal of Toxicology and Environmental Health, Part A, 72, 196-208

Brunetti R., Gabriele M., Valerio P. and Fumagalli O., 1992. The micronucleus test: temporal pattern of baseline-frequency in Mytilus galloprovincialis. Marine Ecology Progress Series $83,75-78$.

Bryan G.W. and Langston W. J., 1992. Bioavailability, accumulation and effect of heavy metals in sediments with special reference to United Kingdom estuaries: a review. Environment Pollution 76, 89-131.

Buchelli T.D. and Fent K., 2009. Induction of cytochrome P450 as a biomarker for environmental contamination in aquatic ecosystems. Critical Reviews in Environmental Science and Technology 25:3, 201-268, DOI: 10.1080/10643389509388479.

Cefas, 2007. A Review of the Contaminant Status of SEA 8 covering the Western Approaches, Celtic Sea and English Channel. Report Ref: C3006/01. 
Ching E.W.K., Siu W.H.L., Lam P.K.S., Xu L., Zhang Y., Richardson B.J. and Wu R.S.S., 2001. DNA adduct formation and DNA strand breaks in green-lipped mussels (Perna viridis) exposed to benzo[a]pyrene: dose- and time-dependent relationships. Mar. Pollut. Bull. 42, 603-610.

Collins A.R., Dusinska M., Gedik C.M. and Stetina R., 1996. Oxidative damage to DNA: do we have a reliable biomarker? Environ Health Prospect 104(S3), 465-469.

Dailianis S., Domouhtsidou G.P., Raftopoulou E., Kaloyianni M. and Dimitriadis V.K., 2003. Evaluation of neural red retention assay, micronucleus test, acetylcholinesterase activity and a signal transduction molecule (cAMP) in tissue of Mytilus galloprovincialis (L.), in pollution monitoring. Marine Environmental Research 56, 443-470.

De Lafontaine Y., Gagné F., Blaise C., Costan G., Gagnon P. and Chan H.M. 2000. Biomarkers in zebra mussels (Dreissena polymorpha) for the assessment and monitoring of water quality of the St Lawrence River (Canada), in Aquatic toxicology 50 (1-2), 51-71. https://doi.org/10.1016/S0166-445X(99)00094-6

Dondero F., Dagnino A., Jonsson H., Caprì F., Gastaldi L. and Viarengo A., 2006. Assessing the occurrence of a stress syndrome in mussels (Mytilus edulis) using a combined biomarker/gene expression approach. Aquatic Toxicology 78S, S13-S24.

Environment Agency (2013). Strategy for managing nitrogen in the Poole Harbour catchment to 2035 :

http://webarchive.nationalarchives.gov.uk/20140328084622/http://www.environmentagency.gov.uk/static/documents/Leisure/Strategy_for_Managing_Nitrogen_in_the_Poole_Har bour_Catchment_Final_06_06_13.pdf

Food Standards Agency, 2017. Designated Bivalve Mollusc Production Areas in England and Wales Effective from 1 September 2017. Available at:

https://www.food.gov.uk/sites/default/files/classification-list-05-feb-18.pdf

Forbes V.E., Palmqvist A., Bach L., 2009. The use and misuse of biomarkers in ecotoxicology. Environmental toxicology and chemistry. https://doi.org/10.1897/05-257R.1

Frenzilli, G., Nigro, M. and Lyons, B.P., 2009. The Comet assay for the evaluation of genotoxic impact in aquatic environments. Mutation Research Reviews in Mutation Research 681, 80-92.

Galloway, T.S., Sanger, R.C., Smith, K.L., Filemann, G., Readman, J.W., Ford, T.E. and Depledge, M.H., 2002. Rapid assessment of marine pollution using multiple biomarkers and chemical immunoassays. Environ. Sci. Technol. 36, 2219-2226.

Humphreys, J. and May, V.J. (Editors) 2005. “The ecology of Poole Harbour”. Proceedings in Marine Science, 7. Elsevier, Amsterdam; Boston., p. 005.

Hutchinson, T.H., Lyons, B.P., Thain, J.E. and Law, R.J., 2013. Evaluating legacy contaminants and emerging chemicals in marine environments using adverse outcome pathways and biological effects-directed analysis. Marine Pollution Bulletin 74, 517-525. 
International Musselwatch Committee, 1992. The international mussel watch: a global assessment of environmental levels of chemical contaminants. International Musselwatch Committee, revised 1992, $122 \mathrm{pp}$.

Kwok A., Lyons B., Hodges N. and Bean T.P., 2013. Cryopreservation and storage of mussels (Mytilus spp.) haemocytes for latent analysis by the Comet Assay. Mutation Research 750, 86-91.

Lam P. K.S. and Gray J. S., 2003. The use of biomarkers in environmental monitoring programmes. Marine Pollution Bulletin 46, 182-186.

Langston, W.J., Pope, N.D., Davey, M., Langston, K.M., O’ Hara, S.C.M. Gibbs, P.E. and Pascoe, P.L., 2015. Recovery from TBT pollution in English Channel environments: A problem solved? Marine Pollution Bulletin 95, 551-564.

Lewis C., Guitart C., Pook C., Scarlett A., Readman J.W. and Galloway T.S., 2010. Integrated assessment of oil pollution using biological monitoring and chemical fingerprinting. Environmental Toxicology and Chemistry 29, 1358-1366.

Loyaza-Muro R. and Elìas-Letts R., 2007. Responses of the mussel Anotontites trapesialis (Unionidae) to environmental stressors: effect of $\mathrm{pH}$, temperature and metals on filtration rate. Environmental Pollution 149, 209-215.

Lyons B., Hylland K., Martìnez-Gòmez C. and Sanni S., 2012. Background document: comet assay as a method for assessing DNA damage in aquatic organism. In: "Integrated marine environmental monitoring of chemicals and their effects" edited by Ian M. Davies I.M. and Vethaak D. ICES Cooperative Research Report No. 315 (2012), pp 54-59.

Magni P., De Falco G., Falugi C., Franzoni M., Monteverde M., Perrone E., Sgro M. and Bolognesi C., 2006. Genotoxicity biomarkers and acetylcholinesterase activity in natural populations of Mytilus galloprovincialis along a pollution gradient in the Gulf of Oristano (Sardinia, western Mediterranean). Environmental Pollution 142, 65-72.

Mamaca E., Bechmann R.K., Torgrimsen S., Aas E., Bjørnstad A., Baussant T. and Le Floch S., 2005. The neutral red lysosomal retention assay and comet assay on haemolymph cells from mussels (Mytilus edulis) and fish (Symphodys melops) exposed to styrene. Aquatic Toxicology 75, 191-201.

Martine-Diaz M.L., Blasco J., Sales D. and DelValls T.A., 2004. Biomarkers as tool to assess sediment quality. Laboratory and field surveys. Trends in analytical chemistry 23, 807-818.

Moore M.N., Lowe D., and Köhler A. 2004. Biological effects of contaminants: Measurement of lysosomal membrane stability. ICES Techniques in Marine Environmental Sciences No.36, 31 .

Nicholson S. and Lam P.K.S., 2005. Pollution monitoring in Southeast Asia using biomarkers in the mytilid mussel Perna viridis (Mytilidae: Bivalvia). Environment International 35, 121132. 
Nicholson S., 2001. Ecocytological and toxicological responses to copper in Perna viridis (L.) (Bivalvia: Mytilidae) haemocyte lysosomal membranes. Chemosphere 45, 399-407.

Nicolaus, E.E.M., Law, R.J., Wright, S.R. and Lyons, B.P., 2015. Spatial and temporal analysis of the risks posed by polycyclic aromatic hydrocarbon, polychlorinated biphenyl and metal contaminants in sediments in UK estuaries and coastal waters. Marine Pollution Bulletin 95, 469-479.

Poole Harbour Steering Group, 2011. Poole Harbour Aquatic Management Plan: 2011 update.: http://www.pooleharbouraqmp.co.uk/

Rank J., Jensen K. and Jespersen P.H., 2005. Monitoring DNA damage in indigenous blue mussels (Mytilus edulis) sampled from coastal sites in Denmark. Mutation Research 585, 3342.

Ringwood A.H., Conners D.E., Hoguet J. and Rinwood L.A., 2005. Lysosomal destabilization assays for estuarine organisms. In "Techniques in Aquatic Toxicology, Volume 2", edited by G. K. Ostrander. CRC Press, Taylor and Francis, Boca Raton, FL. pp. 287-300.

Schettino T., Caricato R., Calisi A., Giordano M. E. and Lionetto M. G., 2012. Biomarker approach in marine monitoring and assessment: new insights and perspectives. Open Environmental Sciences 6, 20-27.

Shaw J.P., Dondero F., Moore M.N., Negri A., Dagnino A., Readman J.W., Lowe D.R., Frickers P.E., Beesley A., Thain J.E. and Viarengo A., 2011. Integration of biochemical, histochemical and toxicogenomic indices for the assessment of health status of mussels from the Tamar Estuary, U.K. Marine Environmental Research 72, 13-24.

Sheahan, D., Brooks, S., Raffo, A., Smedley, C. and Law, R., 2007. A Review of the Contaminant Status of SEA 8 covering the Western Approaches, Celtic Sea and English Channel. Report prepared for Geotek Ltd. 76 pp. Cefas, Lowestoft. Available at: https://www.gov.uk/government/uploads/system/uploads/attachment_data/file/197007/SEA8_ TechRep_Contaminants.pdf

Siu W.H.L., Cao J., Jack R.W., Wu R.S.S., Richardson B.J. and Lam P.K.S. 2004. Application of the comet and micronucleus assays to the detection of $\mathrm{B}[\mathrm{a}] \mathrm{P}$ genotoxicity in haemocytes of the green-lipped mussel (Perna viridis). Aquatic Toxicology 66, 381-392.

Siu W.H.L., Hung C.L.H., Wong H.L., Richardson B.J. and Lam P.K.S., 2003. Exposure and timedependent DNA strand breakage in hepatopancreas of green-lipped mussels (Perna viridis) exposed to Aroclor 1254, and mixtures of B[a]P and Aroclor 1254. Mar. Pollut. Bull. 46, 1285-1293.

Strubbia, S., Lyons, B.P. and Lee, R.L, 2016. Geographical and temporal variation of E. coli and norovirus in mussels. Marine Pollution Bulletin 107, 66-70.

Turner A., 2000. Trace metal contamination in sediments from U.K. estuaries: an empirical evaluation of the role of hydrous iron and manganese oxides. Estuarine, Coastal and Shelf Science 50, 355-371. 
1 Zhao C., Li X., Luo S. and Chang Y., 2011. Assessments of lysosomal membrane responses 2 to stresses with neutral red retention assay and its potential application in the improvement of 3 bivalve aquaculture. African Journal of Biotechnology 10, 13968-13973. 